\title{
NECESSITY AND PECULIARITIES OF REFORMING THE FINANCIAL REPORTING OF AN AGRICULTURAL ENTERPRISE ORIENTED TOWARDS THE ACHIEVEMENT OF STRATEGIC OBJECTIVES OF SUSTAINABLE DEVELOPMENT
}

\section{НЕОБХІДНІСТЬ ТА ОСОБЛИВОСТІ РЕФОРМУВАННЯ ФІНАНСОВОЇ ЗВІТНОСТІ АГРАРНОГО ПІДПРИЕМСТВА, ОРІЄНТОВАНОГО НА ДОСЯГНЕННЯ СТРАТЕГІЧНИХ ЦІЛЕЙ СТАЛОГО РОЗВИТКУ}

\section{Nataliya Gudzenko ${ }^{1}$ \\ Volodimir Metelytsia ${ }^{2}$}

DOI: https://doi.org/10.30525/978-9934-588-53-2-4

Abstract. The efficient economic activity requires the activation of domestic resources and their most efficient use, which implicitly provides the possibility to receive additional competitive advantages. For agricultural enterprises, the problem of ensuring the greening of production, neutralizing the negative impact on the environment, the so-called social and environmental component, is relevant. The efficient management of economic processes of an agricultural enterprise regardless of size and specifics of activity implies the need to ensure an optimal correlation of priorities, risk avoidance, and prediction and uncertainties based on information reflected in the reporting. The aim is to justify theoretical approaches, identify practical recommendations as far as possible to improve the formation of financial and non-financial reporting of agricultural enterprises aimed at the possibility of developing management solutions in sustainable development.

The purpose determines the content of further research which provides the consecutive solution of the following problems of theoretical and applicable nature: studying and generalization of modern approaches to the interpretation of the essence of the reporting and reporting information in domestic and

\footnotetext{
${ }^{1}$ Candidate of Economic Sciences, Associate Professor at the Department of Accounting and Taxation in the Economy, Vinnytsia National Agrarian University, Ukraine

${ }^{2}$ Doctor of Economic Sciences,

Professor at the Department of Accounting and Taxation in the Economy,

Vinnytsia National Agrarian University, Ukraine

(C) Nataliya Gudzenko, Volodimir Metelytsia
} 
international practice, trends and consistent patterns of development of the reporting as an element of a control system focused on the achievement of strategic objectives of sustainable development for optimization of its structure on condition of observance of all principles of formation; systematization of the existing methodical provisions of NPSB, IAS and IFRS concerning forms of financial and social statements, their content, identification of shortcomings for development of offers for improvement of the structure of reporting, recognition, and improvements of certain elements of the reporting; accounting and reporting characteristics of accounting principles and assessment of their practical application in the formation of reporting information are one of the main factors in the formation of accounting policy of the enterprise aimed at optimization of the management system in conditions of sustainable development; studying the possibilities of formation of integrated financial reporting for agrarian enterprises. Methodology. The use of a systematic approach for the study of various aspects of reporting provides an opportunity to identify the peculiarities of reporting information, which requires increased attention from the performers and users and summarizes the results of studies carried out at different stages of economic science development. Induction and extraction methods were used to establish cause and effect relationships between economic processes, operations and individual facts of economic life, to carry out an analytical assessment of existing trends and accounting practices for the possibility of developing proposals for improvement of accounting policy of an enterprise aimed at optimization of the management system.

Research conclusion. It is proposed to complement and broaden the general reporting requirements with fundamental judgments, assumptions, estimates, and limitations used by international practice. These and other features should be taken into account at the accounting stage and reflected in accounting policies as one of the most effective practical tools for improving the quality of reporting information. It is advisable to give preference to fair value estimating procedures, as such a procedure is the most appropriate to ensure the quality of reporting information and to increase the credibility of real and potential users. The reporting needs to be considered as one of the instruments of ensuring social responsibility the role and value of which increases in the possibility of sustainable development of the agrarian enterprises. Therefore it is necessary to pay more attention not to financial information, which increases the effectiveness and efficiency of strategic management. 


\section{1. Вступ}

Глобальні зміни в середовищі функціонування підприємства, процеси стандартизації бухгалтерського обліку вимагають не просто доповнення існуючої практики формування облікових даних та їх узагальнення у звітності, а перегляду теоретичних аспектів та методичних підходів формування та узагальнення звітних даних. Якщо у вітчизняній практиці тривалий час основний акцент здійснювався на кількісні показники, то сучасні умови господарювання та управлінські запити вимагають зміщення акцентів у сторону якісних показників. Отже, сформована в межах облікової системи та попередньо опрацьована інформація про господарські події має бути достовірною та достатньою для можливості прийняття управлінських рішень, орієнтованих на досягнення стратегічних цілей (забезпечення сталого розвитку в довгостроковій перспективі). Зважаючи на те, що стратегічне управління розглядається як вид діяльності, як процес та як система, в обліку та звітності необхідно ці особливості враховувати та передбачити можливість формування інтегрованих показників. Це потребує удосконалення методів і прийомів формування фінансової звітності, використання прогресивних підходів контролю звітних показників, які не дають підстав сумніватися в достовірності та правдивості звітних даних.

За багаторічну історію досліджень, спрямованих на удосконалення системи звітних показників, так і не сформовано єдиного підходу до визначення категорії «звітність», тому звичним явищем $€$ обмеженість інформації, що надається користувачам звітності, викривлення звітних даних з метою представлення господарського процесу та його результатів у більш привабливому вигляді, надмірне узагальнення показників, що не дає можливості адекватної оцінки процесу господарювання без додаткових інформаційних запитів. Висока динамічність, притаманна сучасному економічному розвитку аграрного сектору, вимагає від управлінців розширювати горизонти передбачення основних економічних показників. Для цього система звітності із простої фіксації фактів господарського життя має перетворитися на динамічну «високочутливу», яка оперативно реагує на зміни зовнішнього середовища. Однією із основних проблем теоретичного обгрунтування сутності звітності $\epsilon$ те, що вчені досить часто розглядають ii відособлено: як елемент методу бухгалтерського 
обліку як спосіб узагальнення облікових даних, як систему показників, як комплексне поєднання чітко окреслених звітних форм. Самі по собі ці підходи є правильними і не викликають сумнівів у доречності дослідження, однак в нинішніх умовах звітність необхідно розглядати і вивчати системно і комплексно, адже вона поєднує в собі операції та процеси, які не можливо відобразити одними лише вартісними показниками. У нинішніх умовах звітність - це «кровоносна система» управлінського процесу, яка забезпечує його живлення.

Зважаючи на актуальність дослідження його мета полягає в обгрунтуванні теоретичних підходів, виокремленні практичних рекомендацій щодо можливості удосконалення формування фінансової та не фінансової звітності аграрних підприємств, орієнтованої на можливість розробки стратегічних управлінських рішень за умови сталого розвитку. Для досягнення мети передбачається узагальнити існуючі підходи до трактування сутності звітності та звітної інформації у вітчизняній та міжнародні практиці; іiі характеристики як елемента системи управління, орієнтованого на досягнення стратегічних цілей сталого розвитку; виявлення існуючих недоліків звітних даних з метою розробки пропозицій щодо можливості удосконалення структури звітних форм, визнання та удосконалення окремих елементів звітності; обліково-звітна характеристика принципів обліку та оцінка їхнього практичного застосування при формуванні звітної інформації, що є одним із основних факторів формування облікової політики підприємства, орієнтованої на оптимізацію системи управління в умовах сталого розвитку; вивчення можливостей формування інтегрованої фінансової звітності для підприємств аграрного сектору.

\section{2. Значення звітності в досягненні стратегічних цілей розвитку}

Будь-яке підприємство, здійснюючи свою діяльність, перебуває в середовищі, що характеризується активними кон'юнктурними змінами, високим рівнем конкуренції, відносною нестабільністю економічних умов та відносин. Координація окремих видів господарської діяльності та роботи підприємства в цілому не можлива без належної інформаційної підтримки, роль та значення якої зростає в умовах необхідності забезпечення сталого розвитку усіх складових соціаль- 
но-економічної системи. Популяризація концепції сталого розвитку зумовлена необхідністю екологізації та соціалізації суспільства та вимагає узгодження інтересів економічної, екологічної та соціальної складової. Сталий розвиток - це розвиток, який задовольняє потреби нинішнього покоління і не ставить під загрозу можливість майбутніх поколінь задовольняти їхні власні потреби $[1 ; 6]$. Підприємство в першу чергу розвиває економічну складову, що грунтується на вимозі збереження та розвитку сукупного капіталу, який в подальшому забезпечуватиме можливість створення комплексу ресурсів, необхідного для його поточного та перспективного розвитку.

Сталий економічний розвиток підприємства визначається його здатністю забезпечити можливість зростання виробничих показників за умови дотримання оптимального співвідношення внутрішнього розвитку $з$ навколишнім середовищем екологічного та соціального спрямування. Його можна досягти лише за умови глибокої аналітичної оцінки звітних показників, за результатами якої з'являється можливість оцінити ефективність розміщення й концентрацію капіталу, потенціал зростання віддачі від його подальшого використання за рахунок використання прогресивних технологій, приймати рішення щодо оптимізації його структури та розміщення. Інформаційну базу для стратегічного планування забезпечує система звітності, яка включає фінансову та не фінансову складові. Орієнтація підприємницької діяльності на сталий розвиток передбачає дотримання соціальної відповідальності, яка поєднує комплекс заходів із забезпечення збереження та розвитку трудових ресурсів підприємства (іх мотивації, підвищення кваліфікації тощо), екологічного спрямування підприємницької діяльності.

Успішне функціонування підприємства, зорієнтованого на дотримання принципів сталого розвитку, можливе за умови стратегічного планування. Більшість підприємств застосовують стратегічне планування лише формально, недооцінюючи його переваг в можливості мінімізації ризиків, формуванні оптимальної структури ресурсів відповідно до визначених підприємством напрямів розвитку і завдань.

Будь-яке планування (стратегічне, тактичне, оперативне) забезпечує позитивний ефект лише за умови належного інформаційного забезпечення, яке формує система звітності. На основі аналізу іiі показників користувачі отримують дані про результати минулих гос- 
подарських операцій, можуть оцінити поточний господарський процес та майновий стан, майбутні перспективи продовження діяльності та розвитку. Для забезпечення сталого розвитку стратегічне планування повинно спрямовуватися на можливість зростання виробництва (обсягу надання послуг) для задоволення зростаючих потреб населення при умові дотримання вимог екологічно безпечного господарювання, ефективного використання природних ресурсів, що передбачає відновлення природно-ресурсного потенціалу.

Нинішній формат представлення звітності та ії зміст практично не розкривають екологічну складову, а не фінансова звітність, уособлений Звітом про управління, концентрується переважно на якісних показниках. У не фінансовій звітності (навіть якщо підприємство іiі формує) відсутня інформація про цілі та стратегію вирішення існуючих виробничих проблем, хоча така інформація є найбільш цінною для користувачів: якщо підприємство замається будівництвом, сільським господарством, іншими видами діяльності, які можуть завдати шкоди навколишньому середовищу, у соціальній звітності такий суб'єкт повинен розкривати заходи щодо зниження негативного спливу на довкілля та заходи з відшкодування завданих збитків.

Практика аграрного виробництва за умови інтенсифікації господарських процесів супроводжується негативними екологічними наслідками, що з одного боку забезпечує високу рентабельність, але одночасно погіршує якість грунтів через недотримання сівозміни, внесення значної кількості добрив та засобів захисту в рослинництві та тваринництві, викиди шкідливих речовин в атмосферу внаслідок спалювання рослинних решток, забруднення навколишнього середовища відходами тваринництва. Досвід країн Скандинавії та інших розвинених європейських країн свідчить про те, що без чітко сформованого соціального звіту фінансова звітність не підлягає затвердженню.

Соціальну, не фінансову звітність складають великі компанії, а для малих підприємств та суб'єктів малого підприємництва вона не є обов'язковою, тому такі суб'єкти в більшості випадків намагаються уникнути розкриття негативних сторін своєї діяльності. Однак, користувачів звітності цікавить інформація про наявні проблеми, їх вартісне вираження та можливі шляхи вирішення в конкретних цифрах. Отже, звітність підприємства - це система показників, що деталізують 
інформацію про його діяльність для партнерів, конкурентів, клієнтів, акціонерів та суспільства і дозволяють позиціонувати підприємство на ринку. Її зміст та наповнення не повинні перевантажуватися зайвими показниками, а виступати інструментом для комунікації. Вітчизняна практика формування звітності акцентує увагу на тому, що публічна звітність повинна містити мінімум даних, тоді як світова тенденція більше орієнтована на так звану «розумну» відкритість перед бізнес-партнерами, клієнтами, суспільством, що демонструє вищий рівень довіри, більшу надійність, впевненість стабільній роботі та зменшення ризиків. Тому відкритість підприємства при формуванні звітних показників - стратегія, орієнтована на уникнення інформаційних ризиків, адже одразу інформує користувачів про наявні та можливі проблеми в перспективі, одночасно пропонуючи шляхи їх вирішення у вигляді аналітичних розрахунків, графічних і табличних узагальнень. На їхній основі користувачі приймають рішення про рівень довіри до такого підприємства, і він, як правило, вищий, ніж у підприємства, яке таких даних не надає або свідомо приховує. Тому повнота представлення звітності може розглядатися як конкурентна перевага. Довільний формат представлення не фінансової інформації дає можливість відобразити максимум даних у нестандартній графічній формі, взаємозв'язок між різними звітними формами ускладнює фінансові махінації та фальсифікацію, графічне представлення звітних даних в більшості випадків є достатнім та не вимагає додаткового пояснення та опису, оскільки досить наглядно показує вплив господарського процесу на внутрішнє і зовнішнє середовище існування підприємства. Для того, щоб звітність відповідала вищеописаними вимогам, необхідно забезпечити можливість формування в обліку інтегрованих показників, що поєднують фінансовий, податковий, статистичний та управлінський облік. Звітність повинна бути інформативною, цікавою, корисною і зрозумілою для користувачів.

Для формування звітності підприємства, орієнтованого на досягнення стратегічних цілей сталого розвитку, необхідно забезпечити:

- достовірність показників фінансової і соціальної звітності 3 метою подальшої оцінки результативності соціально-економічних витрат підприємства на реалізацію соціальних програм та екологізацію виробництва; 
- розробити належне облікове забезпечення аналізу доцільності та ефективності соціальних програм та контролю за їх реалізацією шляхом відокремлення витрат на окремому рахунку або субрахунку в обліку та їх подальшого узагальнення у внутрішній та зовнішній звітності;

- здійснювати резервування коштів на реалізацію соціальних та екологічних проєктів, визначених Політикою сталого розвитку, за рахунок прибутку підприємства 3 належним обліковим відображенням наповнення резервів та обов'язковим публічним звітуванням про використання резервних коштів.

Комплексний підхід до формування звітності та вимога повного представлення інформації зумовлені тим, що відсутність чітких вимог та формату представлення звітних даних, особливо за умови формування звітності за МСФЗ, призвели до того, що підприємства детально висвітлюють ті операції та проєкти, які мали позитивний ефект. При цьому суттєвими відмінностями від міжнародної практики складання звітності є відсутність кількісних даних за більшістю описаних якісних показників та відсутність чіткої стратегії вирішення наявних проблем, оцінки їх фінансових наслідків. У результаті користувачі не отримують об'єктивних даних в обсязі, достатньому для прийняття управлінських рішень, що суттєво знижує користь звітної інформації.

Дотримуючись політики сталого розвитку у підприємствах аграрного сектору необхідно чітко визначити та в подальшому дотримуватися принципів «соціальної та екологічної відповідальності ведення бізнесу», що активно поширюється в міжнародній практиці та потребує поглибленого вивчення [5]. За умови використання міжнародного підходу об' єктами розкриття у фінансових звітах є не лише показники, що характеризують фінансовий стан, результати діяльності, грошові потоки та рух капіталу підприємства. Поряд із висвітленням активів, зобов'язань, доходів та витрат, руху грошей вимагається розкриття інформації про зміни в усіх видах використовуваних ресурсів, що в кінцевому результаті дозволяє суттєво розширити масив звітної інформації, що буде оприлюднена. Однак при цьому виникає низка питань, що вимагають вирішення: яку інформацію потребують зацікавлені користувачі, у якій формі ії необхідно представити та яким чином вона буде формуватися в системі обліку? 
Соціально зорієнтований формат представлення звітності вимагає регламентації на початковому етапі його запровадження і може змінюватися за умови зростання соціальної свідомості підприємств, позитивної динаміки формування звітних даних за результатами незалежного контролю.

Одним із напрямів удосконалення звітності є підвищення якості звітних даних. У Законі України «Про бухгалтерський облік та фінансову звітність» та НП(с)БО 1 «Загальні вимоги до фінансової звітності» регламентація здійснюється через вимоги, що окреслені у принципах формування фінансової звітності, обов'язкових якісних характеристиках [7; 8]. Їх дотримання є незаперечним фактом. Звітність за МСФЗ формується за умови дотримання Концептуальної основи, яка вміщує принципи, якісні характеристики, припущення, обмеження. Тому надзвичайно важливо правильно інтерпретувати зміст якісних характеристик.

За результатами наукових досліджень Подолянчук О.А. фундаментальними (основоположними) якісними характеристиками є: доречність і правдиве подання [9, с. 86]. Корисність фінансової інформації посилюється, якщо вона є: зіставною; іiі можна перевірити; вона $\epsilon$ вчасною та зрозумілою [9, с. 86]. Можна погодитися із висновками О.А. Подолянчук, що якісні характеристики фінансової інформації, що підтверджують іiі корисність та розкриваються в Концептуальній основі, визначають типи інформації, що найбільше орієнтовані на зовнішніх користувачів, серед яких існуючі та потенційні інвестори, кредитори, постачальники [9, с. 86].

На міжнародному рівні якості звітної інформації теж приділяється достатньо уваги. Комітетом зі стандартів фінансового обліку (FASB) та Радою з міжнародних стандартів фінансової звітності (IASB) узгоджено поділ якісних характеристик фінансової інформації на основні та підсилюючі. До першої групи, яку можна вважати основоположною, відносять доречність (relevance) і правдиве подання (faithful representation) [10]. Пояснення такого підходу в тому, що інформація повинна подаватися вчасно і бути правдивою, навіть якщо вона суттєво скорочена, а її обсяг недостатній для прийняття рішення. Користувач перш за все повинен бути впевненим у тому, що представлені звітні дані відповідають дійсності, а не «прикрашають» фінансову ситуацію на підприємстві. Інформація вважається доречною і має практичну цін- 
ність, якщо вона суттєва (оцінка проводиться за визначеними в обліковій політиці критеріями суттєвості) і при їі відсутності користувач не може прийняти необхідне рішення, дає можливість прогнозувати майбутні події (передбачувана цінність), що надзвичайно важливо для забезпечення стратегічного розвитку і в більші мірі стосується соціальної відповідальності. Можливість прогнозування часто плутають із необхідністю представлення певних прогнозних розрахунків. Вони не обов'язкові. Однак, звітна інформація повинна забезпечити можливість оцінки потенціалу господарства в основних напрямах його розвитку, відслідковувати тенденції економічної ефективності.

До підсилюючих характеристик віднесено зіставність (comparability), можливість перевірки (verifiability), своєчасність (timeliness) і зрозумілість (understandability). Їх називають підсилюючими, бажаними, з тієї причини, що вони доповнюють основоположні характеристики корисності: якщо звітна інформація $є$ правдивою (виконується основоположна характеристика), вона повинна подаватися у зрозумілому для користувача вигляді зі всіма необхідними поясненнями, що в результаті забезпечує можливість перевірки. Врахування підсилюючих характеристик обумовлено тим, що звітність повинна бути придатною для управління і при цьому орієнтуватися на користувачів, які мають різний рівень сприйняття даних.

При формуванні звітної інформації за МСФЗ необхідно врахувати, що Концептуальна основа не входить до складу МСФЗ і на практиці можуть траплятися випадки протиріччя між принципами $\mathrm{i}$ правилами Концептуальної основи та окремими стандартами. Тому при встановленні такої невідповідності підприємству потрібно керуватися МСФ3, які мають пріоритетне значення.

У вітчизняному законодавстві повністю ігнорується така якісна характеристика як нейтральність звітної інформації. Враховуючи міжнародну практику, нейтральність - це неупередженість при формуванні та відображенні звітної інформації, відсутність ризику свідомого маніпулювання за допомогою звітності. Порівняння якісних характеристики фінансової інформації представлено у таблиці 1.

Основні та підсилюючі якісні характеристики необхідно правильно застосовувати. Концептуальна основа МСФЗ [10] пропонує таку послідовність їх застосування. 
Якісні характеристики фінансової інформації

\begin{tabular}{|c|c|c|c|}
\hline \multirow{2}{*}{\multicolumn{2}{|c|}{$\begin{array}{c}\text { За концептуальною основою } \\
\text { Основоположні }\end{array}$}} & \multirow{2}{*}{\multicolumn{2}{|c|}{ За НП(С)БО }} \\
\hline & & & \\
\hline Доречність & $\begin{array}{l}\text { фінансова інформація } \\
\text { може спричинити від- } \\
\text { мінності у рішеннях, які } \\
\text { приймають користувачі; } \\
\text { фінансова інформа- } \\
\text { ція може спричинити } \\
\text { відмінності у рішеннях, } \\
\text { якщо вона має перед- } \\
\text { бачувану цінність, під- } \\
\text { тверджувальну цінність } \\
\text { або і те, і те. }\end{array}$ & Доречність & $\begin{array}{l}\text { фінансова звітність } \\
\text { повинна містити } \\
\text { лише доречну інфор- } \\
\text { мацію, яка впливає } \\
\text { на прийняття рішень } \\
\text { користувачами, дає } \\
\text { змогу вчасно оцінити } \\
\text { минулі, теперішні } \\
\text { та майбутні події, } \\
\text { підтвердити та ско- } \\
\text { ригувати їхні оцінки, } \\
\text { зроблені у минулому. }\end{array}$ \\
\hline $\begin{array}{l}\text { Правдиве } \\
\text { подання }\end{array}$ & \begin{tabular}{|l|} 
щоб бути досконало \\
правдивим поданням, \\
опис повинен мати три \\
характеристики. Він має \\
бути: повним, нейтраль- \\
ним, вільним від помилок.
\end{tabular} & \multirow[t]{2}{*}{ Достовірність } & \multirow{2}{*}{$\begin{array}{l}\text { iнформація, наведена } \\
\text { у фінансовій звітності, } \\
\epsilon \text { достовірною, якщо } \\
\text { вона не містить поми- } \\
\text { лок та перекручень, } \\
\text { які здатні вплинути на } \\
\text { рішення користувачів } \\
\text { звітності. } \\
\end{array}$} \\
\hline & Посилюючі & & \\
\hline Зіставність & $\begin{array}{l}\text { характеристика, яка } \\
\text { дає змогу користувачам } \\
\text { ідентифікувати та зрозу- } \\
\text { міти подібності статей і } \\
\text { відмінності між ними. }\end{array}$ & Зіставність & \begin{tabular}{|l} 
передумовою зістав- \\
ності є наведення від- \\
повідної інформації \\
попереднього періоду \\
та розкриття інфор- \\
мації про облікову \\
політику і її зміни. \\
\end{tabular} \\
\hline $\begin{array}{l}\text { Можливість } \\
\text { перевірки }\end{array}$ & $\begin{array}{l}\text { допомагає запевнити } \\
\text { користувачів у тому, що } \\
\text { інформація правдиво } \\
\text { подає економічні явища, } \\
\text { які вона призначена } \\
\text { подавати. }\end{array}$ & Порівнюваність & $\begin{array}{l}\text { фінансова звітність } \\
\text { повинна надавати мож- } \\
\text { ливість користувачам } \\
\text { порівнювати: фінансові } \\
\text { звіти підприємства за } \\
\text { різні періоди; фінансові } \\
\text { звіти різних підприємств. }\end{array}$ \\
\hline Своєчасність & $\begin{array}{l}\text { можливість для осіб, які } \\
\text { приймають рішення, мати } \\
\text { інформацію вчасно так, } \\
\text { щоб ця інформація могла } \\
\text { вплинути на їхні рішення. }\end{array}$ & \multirow{2}{*}{$\begin{array}{l}\text { Дохідливість } \\
\text { і зрозумілість }\end{array}$} & \multirow{2}{*}{\begin{tabular}{|l} 
інформація, яка \\
надається у фінансовій \\
звітності, повинна бути \\
дохідлива і зрозуміла \\
її користувачам за \\
умови, що вони мають \\
достатні знання та \\
заінтересовані у сприй- \\
нятті цієї інформації.
\end{tabular}} \\
\hline Зрозумілість & $\begin{array}{l}\text { класифікація, охаракте- } \\
\text { ризування та подання } \\
\text { інформації ясно і стисло } \\
\text { робить ії зрозумілою. }\end{array}$ & & \\
\hline
\end{tabular}

Джерело: [9, с. 86] 
1. Визначити перелік найбільш суттєвих для користувачів економічних процесів або операцій, до розкриття яких у звітності необхідно підійти особливо ретельно.

2. Установити яка інформація є доречною та вимагає особливого розкриття і деталізації та на скільки детально її можна висвітлювати без шкоди для підприємства.

Визначити рівень доступності можливого відображення інформації. На даному етапі особлива роль належить підсилюючим якісним характеристикам: вони обираються індивідуально виходячи із особливостей звітної інформації, що відображається.

Незаперечною перевагою застосування Концептуальної основи $\epsilon$ цілеспрямованість збору, опрацювання та узагальнення інформації про господарські операції у звітності.

Для розуміння сутності та особливостей застосування основних та посилюючих якісних характеристик варто узагальнити існуючу практику в таблиці 2.

Отже, основний акцент при підготовці звітності необхідно зосередити на доречності та правдивості звітної інформації, виключаючи вплив навмисних і ненавмисних помилок, які спотворюють звітні дані. Серед підсилюючих якісних характеристик на першому місці зіставність, оскільки ії дотримання вимагають усі групи користувачів.

Таблиця 2

\section{Розмежування якісних характеристик звітної інформації}

залежно від користувачів та їх інформаційних потреб

\begin{tabular}{|c|c|c|c|c|c|}
\hline \multicolumn{2}{|c|}{ Суб'скти звітування } & 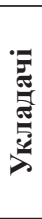 & 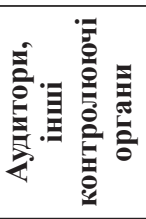 & 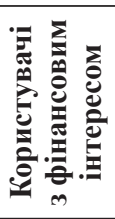 & 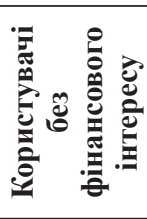 \\
\hline \multirow[b]{2}{*}{ Основоположні } & Доречність & + & + & + & + \\
\hline & $\begin{array}{c}\text { Правдиве } \\
\text { подання }\end{array}$ & + & + & + & + \\
\hline \multirow{4}{*}{ Підсилюючі } & Зіставність & + & + & + & + \\
\hline & $\begin{array}{c}\text { Можливість } \\
\text { перевірки }\end{array}$ & + & + & + & - \\
\hline & Своєчасність & + & - & + & + \\
\hline & Зрозумілість & - & - & + & + \\
\hline
\end{tabular}




\section{3. Оцінка, розкриття, можливості удосконалення елементів фінансової звітності}

Збалансований та цілеспрямований розвиток підприємства у перспективі можливий за умови ефективного управління, що базується на звітних показниках. Тому орієнтація на сталий розвиток вимагає пошуку ефективних, науково обгрунтованих розробок у сфері управління, забезпечення стабільного і прибуткового функціонування підприємства. У результаті інформація перетворюється на стратегічний ресурс окремого підприємства, що бере участь у забезпеченні максимально корисного економічного ефекту поряд 3 іншими видами ресурсів.

На практиці у звітності відображаються лише ті операції, які відбулися, однак міжнародна практика передбачає можливість відображення намірів щодо здійснення господарських операцій.

Головним завданням, яке вимагає вирішення на рівні організації обліково-звітної роботи є забезпечення єдності інформації та управлінських потреб: система звітних показників повинна бути не перевантажена даними, бо тоді знижується ії корисність. Необхідно досягти балансу між затребуваністю інформації та її обсягом. У нинішніх умовах у більшості підприємств ця вимога не виконується. Однак, досягти потрібної збалансованості можна за рахунок єдності систем обліку, аналізу та контролю з метою оптимізації управління економічними процесами та досягнення завдань стратегічного розвитку (рис. 1).

Інформація, узагальнена у формах звітності, повинна включати фінансову та не фінансову складові та відображати не лише майновий стан і ресурсне забезпечення, результати господарювання, а й наміри щодо ймовірного здійснення операцій, що характеризуються високим ступенем ризику, що в подальшому забезпечить можливість управління ризиками та мінімізувати їх негативний вплив. Не фінансовій інформації відводиться допоміжна роль, а основну перевагу має фінансова звітність.

Порядок складання та подання фінансової звітності більш-менш чіткий, оскільки регламентується законодавством. Щодо не фінансової звітності, яка відображає якісні, соціальні показники, при іiі формуванні потрібно виходити із поняття «корисності для управління». Її визначають за результатами проведеного аналізу, який виявляє наявні 
Nataliya Gudzenko, Volodimir Metelytsia

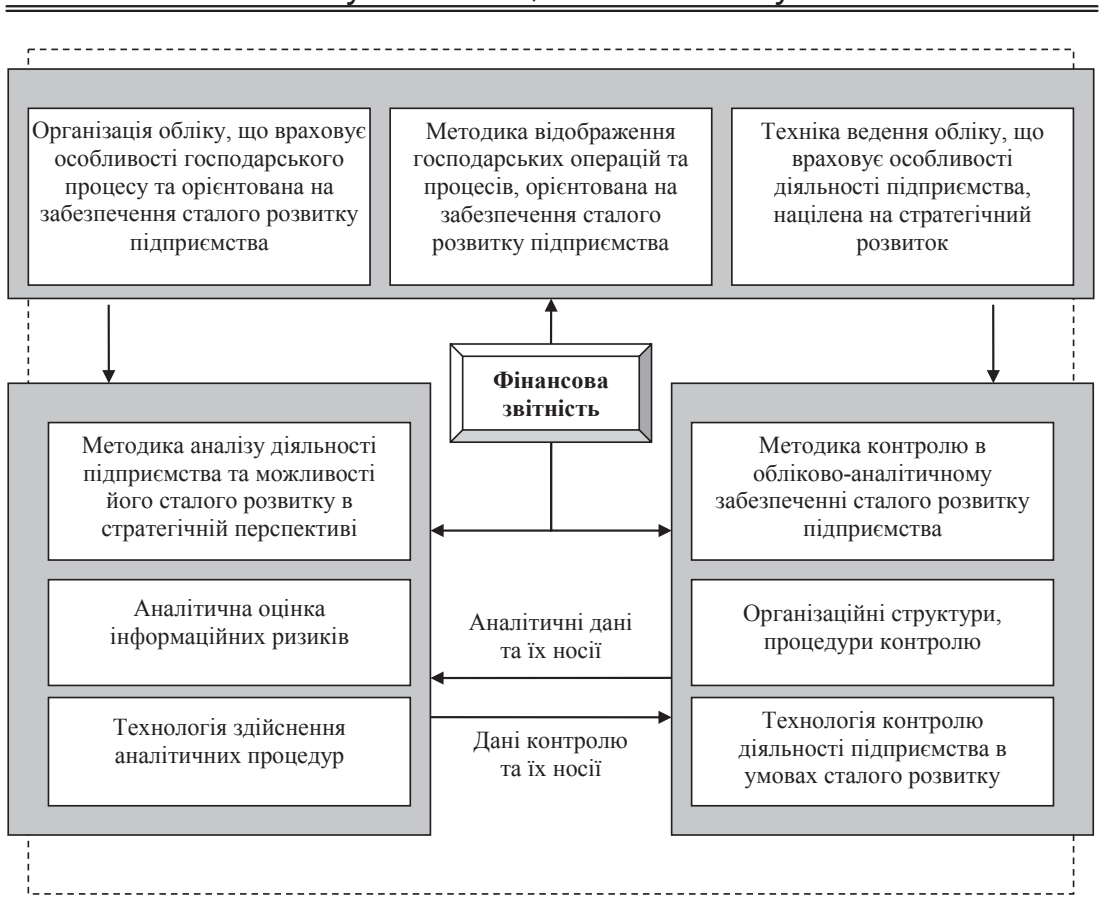

\section{Рис. 1. Місце фінансової звітності у формуванні інформаційного забезпечення обліково-аналітичної системи управління}

прогалини і недоліки та рекомендує шляхи їх усунення та у ході здійснення контрольних процедур. Отже, якщо потрібна для користувачів інформація у звітності не відображена, то це комплексна проблема, яка вимагає коригування передусім методики організації обліку, бо тільки в такий спосіб можна досягти оптимального результату. З позиції звітності корисність - це властивість активу (звітного елементу) генерувати приріст ресурсів і отримання економічної вигоди у процесі ï використання. Корисність є визначальним критерієм оцінки вартості, адже один і той самий звітний елемент в різних умовах може мати різну вартість, є вирішальним фактором при здійсненні переоцінки.

Методичними рекомендаціями щодо складання фінансової звітності чітко встановлено перелік форм, необхідних для представлення та ї зміст [12]. 
При формуванні звітності важливо правильно окреслити оціночні судження, адже їх не можливо перевірити на предмет відповідності дійсності. За цими судженнями формуються резерви, здійснюється розподіл доходів та витрат між періодами, тому можна зробити висновок про те, що оціночні судження мають опосередкований вплив на фінансовий результат та фінансово-майновий стан. Міжнародні стандарти пропонують достатньо широкий перелік випадків, коли можливе застосування професійних суджень при складанні звітності. Так, на відміну від вітчизняної практики у МСБО та МСФЗ визначені методичні підходи до застосування професійного судження.

Таблиця 3

\section{Основні компоненти фінансової звітності та їх призначення}

\begin{tabular}{|c|c|c|c|}
\hline $\begin{array}{c}\text { Форма i } \\
\text { компонент }\end{array}$ & Зміст & $\begin{array}{c}\text { Використання } \\
\text { інформації }\end{array}$ & $\begin{array}{c}\text { Інформація, яка } \\
\text { не відображається, } \\
\text { але може бути } \\
\text { корисною для } \\
\text { управління }\end{array}$ \\
\hline $\begin{array}{l}\text { Ф. № } 1 . \text { Баланс } \\
\text { підприємства } \\
\text { (Звіт про фінан- } \\
\text { совий стан) }\end{array}$ & $\begin{array}{l}\text { Наявність еконо- } \\
\text { мічних ресурсів, } \\
\text { які контролю- } \\
\text { ються підприєм- } \\
\text { ствами на дату } \\
\text { балансу. }\end{array}$ & $\begin{array}{l}\text { Оцінка струк- } \\
\text { тури ресурсів } \\
\text { підприємства, } \\
\text { їх ліквідності та } \\
\text { платоспроможно- } \\
\text { сті; прогнозування } \\
\text { майбутніх потреб } \\
\text { у позиках; оцінка } \\
\text { та прогнозування } \\
\text { змін в економіч- } \\
\text { них ресурсах, } \\
\text { які підприємство } \\
\text { контролюватиме в } \\
\text { майбутньому }\end{array}$ & $\begin{array}{l}\text { Відсутня інформа- } \\
\text { ція щодо величини } \\
\text { доходів і витрат } \\
\text { майбутніх періодів, } \\
\text { оскільки більшість } \\
\text { підприємств не вва- } \\
\text { жають за потрібне } \\
\text { їх виокремлювати. } \\
\text { Відверте «неба- } \\
\text { жання» формувати } \\
\text { резерви, в тому числі } \\
\text { на покриття неперед- } \\
\text { бачуваних витрат }\end{array}$ \\
\hline $\begin{array}{l}\text { Ф. № 2. Звіт } \\
\text { про фінансові } \\
\text { результати (Звіт } \\
\text { про сукупний } \\
\text { дохід) }\end{array}$ & $\begin{array}{l}\text { Доходи, витрати і } \\
\text { фінансові резуль- } \\
\text { тати діяльності } \\
\text { підприємства за } \\
\text { звітній період. }\end{array}$ & $\begin{array}{l}\text { Оцінка та прогноз } \\
\text { прибутковості } \\
\text { діяльності підпри- } \\
\text { ємства; структури } \\
\text { доходів та витрат }\end{array}$ & $\begin{array}{l}\text { Не дає чіткого уяв- } \\
\text { лення про величину } \\
\text { скупного доходу, } \\
\text { оскільки в обліку } \\
\text { відсутня прозора і } \\
\text { зрозуміла методика } \\
\text { його визначення }\end{array}$ \\
\hline
\end{tabular}


(Закінчення таблиці 3)

\begin{tabular}{|c|c|c|c|}
\hline $\begin{array}{c}\text { Форма i } \\
\text { компонент }\end{array}$ & Зміст & $\begin{array}{c}\text { Використання } \\
\text { інформації }\end{array}$ & $\begin{array}{c}\text { Інформація, яка } \\
\text { не відображається, } \\
\text { але може бути } \\
\text { корисною для } \\
\text { управління }\end{array}$ \\
\hline $\begin{array}{l}\text { Ф. № 3. Звіт про } \\
\text { рух грошових } \\
\text { коштів }\end{array}$ & $\begin{array}{l}\text { Генерування та } \\
\text { використання } \\
\text { грошових коштів } \\
\text { протягом звітного } \\
\text { періоду. }\end{array}$ & $\begin{array}{l}\text { Оцінка та прогноз } \\
\text { операційної, інвес- } \\
\text { тиційної та фінан- } \\
\text { сової діяльності } \\
\text { підприємства }\end{array}$ & $\begin{array}{l}\text { Відсутність можли- } \\
\text { вості оцінки руху } \\
\text { грошових коштів у } \\
\text { режимі реального } \\
\text { часу }\end{array}$ \\
\hline $\begin{array}{l}\text { Ф. № 4. Звіт про } \\
\text { власний капітал }\end{array}$ & $\begin{array}{l}\text { Зміни у складі } \\
\text { власного капіталу } \\
\text { підприємства } \\
\text { протя-гом звітного } \\
\text { періоду. }\end{array}$ & $\begin{array}{l}\text { Оцінка та прогноз } \\
\text { змін у власному } \\
\text { капіталі }\end{array}$ & \\
\hline $\begin{array}{l}\text { Ф. № } 5 . \\
\text { Примітки до } \\
\text { річної фінансо- } \\
\text { вої звітності }\end{array}$ & $\begin{array}{l}\text { Обрана облі- } \\
\text { кова політика. } \\
\text { Інформація, не } \\
\text { наведена без- } \\
\text { посе-редньо у } \\
\text { фінансових звітах, } \\
\text { але обов'яз- } \\
\text { кова за П(С)БО. } \\
\text { Додатковий аналіз } \\
\text { статей звітності, } \\
\text { необхідний для } \\
\text { забезпечення їі } \\
\text { зрозумілості. }\end{array}$ & $\begin{array}{l}\text { Оцінка та прогноз } \\
\text { облікової полі- } \\
\text { тики; ризиків або } \\
\text { невпевненості, } \\
\text { які впливають на } \\
\text { підприємство, } \\
\text { його ресурси та } \\
\text { зобов'язання; } \\
\text { діяльності підроз- } \\
\text { ділів підприєм- } \\
\text { ства, тощо }\end{array}$ & \\
\hline
\end{tabular}

Джерело: сформовано на основі узагальнення [12]

Суттєві розбіжності між національним та міжнародними стандартами виявляються в пріоритетах оцінки: МСФЗ надають перевагу оцінці за справедливою вартістю, тоді як у ПСБО окреслено лише загальні підходи до застосування цього методу оцінки через складність його застосування. Застосування методу оцінки за справедливою вартістю найбільше зі всіх прийомів забезпечує достовірність звітних даних, підвищує довіру зовнішніх користувачів звітності, адже відображає операції за їх реальною вартістю, позбавленою припущень, умовностей, упереджень, що мінімізує інформаційні ризики. 
Аграрні підприємства залежно від розміру готують та подають звітність у повному або скороченому форматі (для суб'єктів малого підприємництва). Суб'єкти малого підприємництва не використовують МСБО та МСФ3, права на довільне представлення елементів Балансу не мають, оскільки міжнародні стандарти не передбачають суворого формату відображення інформації про майновий стан, окреслюючи лише загальні правила, допустимі альтернативи щодо визнання і розкриття інформації в балансі та обмеження. У МСБО 1 наведено лише мінімальний перелік статей Балансу та передбачено можливість приєднання/об'єднання додаткових статей, заголовків, проміжних підсумків у разі потреби. Для забезпечення можливості альтернативного вибору пропонується лише перелік обов'язкових до представлення статей (основні засоби; інвестиційна нерухомість; нематеріальні, фінансові, біологічні активи; інвестиції, запаси, дебіторська та кредиторська заборгованість; грошові кошти; забезпечення і резерви; фінансові зобов'язання; капітал), оцінку яких рекомендовано проводити за справедливою вартістю. Решта інформації відображається на розсуд підприємства виходячи із суттєвості та відповідності якісним характеристикам.

Використання справедливої вартості зумовлено тим, що звітні дані Балансу використовуються для аналізу ліквідності, платоспроможності, фінансової стійкості та ділової активності, тому вартісне вираження балансових статей повинно бути максимально реалістичним.

Грошовим виразом вартості $є$ ціна. На практиці досить часто ціна прирівнюється до оцінки, але таке припущення не правильне. Ціна формується під впливом попиту і пропозиції, а вартість - ймовірна величина, яка визначається розрахунковим способом на підставі прогнозованих подій та припущень. Проблема оцінки балансових статей на сьогоднішній день найбільш актуальна, оскільки припущень i обмежень при іiі розрахунку на стільки багато, що в окремих випадках всю їх кількість (економічну нестабільність, валютні коливання, зміна податкової політики тощо) врахувати не реально.

Міжнародна практика формування Балансу використовує принципово відмінний від вітчизняного підхід щодо розмежування активів і зобов'язань на поточні і непоточні. Альтернативність вибору пояснюється тим, що МСБО та МСФЗ, надаючи право вибору формату звітності та їі змісту, орієнтуються на економічну сутність відображуваних 
об'єктів та здоровий глузд. Альтернатива формату подачі фінансової інформації не розглядається як інструмент фальсифікацій по причині достатнього рівня соціально свідомої культури представлення звітних даних, усвідомленої відповідальності за можливі наслідки у випадку їх фальсифікації, навмисного викривлення.

Суттєвим недоліком вітчизняної практики відображення в Балансі активів $\epsilon$ нівелювання так званими «специфічними» активами, до яких можна віднести інвестиційну нерухомість. У Балансі більшості підприємств вона не виділяється, хоча такими активами вони фактично володіють. Приєднання інвестиційної нерухомості до основних засобів не порушує економічну сутність цього виду активів, але досить складно в такому випадку простежити можливість генерування економічної вигоди, зв'язок активу із доходом, отримання його можливе при умові використання інвестиційних вкладень у нерухомість. Якщо розглядати перспективу забезпечення сталого розвитку, то структуру активів варто доповнити ресурсами, що можуть використовуватися для соціалізації та екологізації виробництва.

Надзвичайно важливим є достовірне відображення в Балансі структури капіталу, що впливає на прогнозування майбутніх потреб у позиках, у процесі розподілу очікуваних фінансових результатів та грошові потоки, в тому числі з метою їх оптимізації, потоків грошових коштів, можливості залучення капіталу. Також вимагає уточнення виокремлення інформації щодо довгострокових і поточних забезпечень. Їх можна розглядати в якості своєрідних резервів, які використовуються для покриття очікуваних витрат.

Проблема звітності полягає в тому, що дані обліку прирівнюють цінність активу до вартості його придбання, тоді як користувачі намагаються оцінити актив 3 точки зору очікуваної віддачі від його використання в перспективі. Саме різниця між цінністю активу, яка може відрізнятися за одним і тим самим активом в різних підприємствах, та його вартістю придбання показує справедливу величину фінансового результату. Вітчизняний облік та звітність цінність активів не визначають та не відображають, що негативно впливає на якість відображуваних даних.

На теперішній час в обліку практично відсутня єдність у методиці оцінки, прийнятної для характеристики фінансового стану господарю- 
ючого суб'єкта, результатів його діяльності у такому вигляді, який би задовольняв потреби користувачів. Методика оцінки може змінюватися залежно від мети оцінювання та економічних інтересів суб' єктів звітування. Якщо більшість елементів звітності відображені за історичною собівартістю, а користувачі вимагають представлення даних за реальною вартістю і здійснюється перерахунок таких статей, то виникає загроза штучного завищення або заниження фінансового результату, втрачається його зв'язок з показниками ефективності, а сама проблема поглиблюється нестабільністю економічних відносин та інфляцією. Тому рекомендується основні статті звітності, які використовуються для розрахунку аналітичних показників і $є$ суттєвими, представляти у звітності за справедливою вартістю. Доречним буде згадати принцип «обачності», який виключений із Закону «Про бухгалтерський облік і фінансову звітність», але не втрачає своєї актуальності.

Наявні ресурси будь-яке підприємство використовує з метою отримання прибутку, що підтверджує ефективність і результативність діяльності. Тому звітність повинна забезпечити можливість оцінки результату використання активів, величину їх «реальної корисності». Необхідність такої оціни обумовила те, що Звіт про фінансові результати входить до спрощеної звітності, адже він дає змогу простежити залежність між вартістю, втіленою в активах, та іiі здатністю генерувати реальний результат. Він показує цінність наявних ресурсів. Основними його елементами $€$ доходи, витрати і фінансові результати, тому основним завданням $\epsilon$ достовірність їх оцінки та визначення. Складність пристосування Звіту про фінансові результати до потреб системи управління обумовлена існуючими протиріччями та невідповідностями в економічному трактуванні сутності фінансового результату (парадокси прибутку), в результаті чого у звітності відображається «віртуальний» результат. На практиці виникає ситуація, коли за розрахунковими даними господарство отримало прибуток, а фактично величина прибутку суттєво менша, ніж розрахована. Причиною такої невідповідності є застосування принципу нарахування, за яким дохід визнається в момент передачі права власності, а його фізичний рух відбувається в момент оплати. Передбачити можливість погашення заборгованості дебітором практично не можливо. Якщо визнаний в обліку та відображений у звітності доход не буде «матеріалізованим» за фактом оплати через визнання дебі- 
тора банкрутом, а заборгованості визнана безнадійною, підприємство повинно відкоригувати фінансовий результат у бік зменшення. На перший погляд такі коригування не складають труднощів щодо техніки розрахунку. Однак, якщо така ситуація виникла в попередніх періодах, то капіталізована в Балансі частина «зайвого» прибутку буде спотворювати загальний фінансовий стан. Якщо підприємство більшість доходу отримує за фактом передоплати, то чинну методику можна вважати цілком прийнятною.

Важливе значення для управління та забезпечення сталого розвитку має відображення у звітності сукупного доходу. Згідно 3 п. 3 p. 1 НП(С)БО 1 [8] сукупний дохід - це зміни у власному капіталі господарюючого суб'єкта, результатів протягом звітного періоду внаслідок господарських операцій та інших подій (за винятком змін капіталу за рахунок операцій із власниками).

Звіт про фінансові результати, на відміну від статичного Балансу, який можна вважати «фотокарткою бізнесу» внаслідок його формування на конкретну дату, є динамічним, має стратегічне спрямування, оскільки дає можливість оцінити здатність підприємства розвиватися та успішно функціонувати. Високі кредитні ставки за кредитними ресурсами банківської сфери збільшують роль та значення прибутку як основного джерела фінансування, що забезпечує сталий розвиток.

Зважаючи на вищенаведене, вважаємо доцільним зобов'язати підприємства до формування обов'язкових приміток до Звіту про фінансові результати, які пояснюватимуть економічну природу відображених у самому звіті доходів і витрат за видами, дозволятимуть оцінювати їхній вплив на фінансовий результат, що в загальному забезпечить високий рівень довіри з боку користувачів. Запозичення 3 міжнародної практики методики управління доходами при вмілому застосуванні іiї елементів дозволяс маніпулювати фінансовими результатами та подавати інформацію в привабливому вигляді, що вводить в оману користувачів, підштовхуючи їх до хибних рішень.

\section{4. Висновки}

Розглядаючи звітність в якості одного з інструментів досягнення стратегічних цілей сталого розвитку аграрного підприємства необхідно враховувати цілі сталого розвитку, орієнтовані на оптимальне 
поєднання ефективного виробництва сільськогосподарської продукції 3 мінімальним забрудненням довкілля та одночасним забезпеченням соціального розвитку сільських територій, на яких здійснюється таке виробництво. В таких умовах важливим та необхідним є дотримання комплексного підходу до формування системи звітних показників, які певною мірою можна вважати інформаційним ресурсом, а їх використання забезпечуватиме сталий розвиток підприємства.

Доведено необхідність подальшого реформування звітності у напрямку іiі гармонізації з міжнародними стандартами, що вимагає одночасного удосконалення організації і методики обліку. Пропонується доповнити і розширити загальні вимоги до складання звітності істотними судженнями, припущеннями, оціночними значеннями та обмеженнями, які використовує міжнародна практика. Ці та інші особливості потрібно врахувати на етапі організації обліку та відобразити в обліковій політиці, як одному із найбільш дієвих практичних інструментів удосконалення якості звітної інформації.

За результатами проведених досліджень враховуючи прямий вплив достовірності звітних даних на результати поточного і стратегічного аналізу вважаємо за доцільне популяризацію оцінки за справедливою вартістю, вважаючи цей метод найбільш прийнятним для забезпечення належної якості звітної інформації та підвищення довіри до неї з боку реальних та потенційних користувачів.

Звітність необхідно розглядати як один з інструментів гарантування соціальної відповідальності, роль і значення якої зростає в забезпеченні можливості сталого розвитку аграрних підприємств. Тому необхідно більше уваги приділяти не фінансовій інформації, яка підвищує результативність та ефективність стратегічного управління. Майновий стан аграрного підприємства оцінюється його ресурсами, однак у звітності нинішнього формату практично не можливо знайти інформацію про ресурсний потенціал сталого розвитку.

Звіт про фінансові результати входить дає змогу простежити залежність між вартістю, втіленою в активах, та іï здатністю генерувати реальний результат. Він показує цінність наявних ресурсів.

Для забезпечення сталого розвитку аграрного підприємства необхідно забезпечити відображення у звітності реальної величини ії елементів. Тому зважаючи на розбіжності трактування сутності ціни, вартості, 
оцінки, доведено необхідність розглядати вартість як витрати на створення, придбання об'єкту, який вперше береться на баланс підприємства. Натомість, цінність визнано економічною категорією, що виражає відносини обміну між зацікавленими сторонами, їх ставлення до об'єкта угоди. Таке розмежування дозволяє підвищити якість звітної інформації.

\section{Список літератури:}

1. Корнійчук Л. Теоретичні основи реалізації концепції сталого розвитку. Економіка України. 2010. № 2(579). С. 72-83.

2. Отенко І.П. Формування інформаційного простору підприємств у міжнародному бізнес-середовищі. Бізнес Інформ. 2016. № 9. С. 236-240. URL: http://nbuv.gov.ua/UJRN/binf_2016_9_38 (дата звернення: 20.04.2020).

3. Дикий А.П., Грицишен Д.О. Соціальне звітування суб’єктів господарювання як інструмент забезпечення сталого розвитку. Вісник Житомирського державного технологічного університету. Серія: Економічні науки. 2011. № 1(55). C. 63-68.

4. О чем молчат нефинансовые отчеты. Дело. URL: https://delo.ua/business/ o-chem-molchat-nefinansovye-otche-142846 (дата звернення: 26.04.2020).

5. Дєліні М.М. Напрями оцінки соціально-економічної відповідальності підприємництва. Збірник наукових пращь «Проблеми системного підходу в економіці». 2017. Вип. 4(60). С. 131-137.

6. Сиротюк Г. Концептуальні засади сталого розвитку аграрних підприємств. Аграрна економіка. 2018. Т. 11, № 3-4. С. 87-95. URL: http://agrarianeconomy.kl.com.ua/agrarianeconomy/images/docs/ae_2018_ 11_3-4/13.pdf (дата звернення: 20.04.2020).

7. Про бухгалтерський облік та фінансову звітність в Україні: Закон України від 16 липня 1999 року № 996-XIV. URL: http://zakon3.rada.gov.ua/ laws/show/996-14_(дата звернення: 20.04.2020).

8. Національне положення (стандарт) бухгалтерського обліку 1 «Загальні вимоги до фінансової звітності» : Наказ Міністерства фінансів України від 07.02.2013 p. № 73. URL: http://zakon4.rada.gov.ua (дата звернення: 20.04.2020).

9. Подолянчук О.А. Облікова інформація та її якісні характеристики відповідно до облікових стандартів. Економіка. Фінанси. Менеджмент: актуальні питання науки і практики. 2018. № 8. С. 79-90.

10. Панченко I. Вимоги до інформації, що міститься у фінзвітності, складеній за МСФЗ. URL: https://uteka.ua/ua/publication/commerce-12-msfo-28trebovaniya-k-informacii-v-finotchetnosti-sostavlennoj-po-msfo (дата звернення: 29.04.2020).

11. Фесенко В.В., Загорельсьска Т.Ю. Облікові викривлення та їх вплив на фінансову звітність. Глобальні та національні проблеми економіки. 2015. Вип. 5. С. 1040-1043.

12. Методичні рекомендації щодо заповнення форм фінансової звітності: Наказ Міністерства фінансів України 28.03.2013 р. № 433. 
URL: http://minfin.kmu.gov.ua/control/uk/publish/article/main?art_id=382876\&search param $=\% \mathrm{EE} \% \mathrm{E} 1 \% \mathrm{~B} 3 \% \mathrm{E} 3 \&$ searchPublishing=1 (дата звернення: 22.04.2020).

13. Національне Положення (стандарт) бухгалтерського обліку 25 «Спрощена фінансова звітність». Наказ Міністерства фінансів України від 25.02.2000 p. № 39 зі змінами від 31.05.2019 p. № 226. URL: https://ips.ligazakon.net/ document/view/REG4382?an=5 (дата звернення: 25.04.2020).

\section{References:}

1. Kornijchuk, L. (2010). Teoretychni osnovy realizaciji koncepciji stalogho rozvytku [Theoretical bases of realization of the concept of sustainable development]. Ukraine economy, no. 2(579), pp. 72-83.

2. Otenko, I. P. (2016). Formuvannja informacijnogho prostoru pidpryjemstv u mizhnarodnomu biznes-seredovyshhi [Formation of information space of enterprises in the international business environment]. Biznes Inform [Business Inform] (electronic journal), no. 9, pp. 236-240. Retrieved from: http://nbuv.gov.ua/UJRN/ binf_2016_9_38 (accessed 20 April 2020).

3. Dykyj, A. P., \& Ghrycyshen, D. O. (2011). Socialjne zvituvannja sub'jektiv ghospodarjuvannja jak instrument zabezpechennja stalogho rozvytku [Social reporting of business entities as a tool for sustainable development]. Visnyk Zhytomyrsjkogho derzhavnogho tekhnologhichnogho universytetu [Bulletin of Zhytomyr State Technological University], vol. Economic sciences, no. 1(55), pp. 63-68.

4. Vorobey, V. (2010). O chem molchat nefinansovye otchety [About which the financial statements are silent]. Delo (electronic journal). Retrieved from: https://delo.ua/business/o-chem-molchat-nefinansovye-otche-142846 (accessed 26 April 2020).

5. Djelini, M. M. (2017). Naprjamy ocinky socialjno-ekonomichnoji vidpovidaljnosti pidpryjemnyctva [Directions for assessing the socio-economic responsibility of entrepreneurship]. Zbirnyk naukovykh pracj «Problemy systemnogho pidkhodu v ekonomici» [Collection of scientific works «Problems of system approach in economy»]. Kiev, vol. 4(60), pp. 131-137.

6. Syrotjuk, Gh. (2018). Konceptualjni zasady stalogho rozvytku aghrarnykh pidpryjemstv [Conceptual principles of sustainable development of agricultural enterprises]. Aghrarna ekonomika [Agricultural economy] (electronic journal), vol. 11, no. 3-4, pp. 87-95. Retrieved from: http://agrarianeconomy.kl.com.ua/ agrarianeconomy/images/docs/ae_2018_11_3-4/13.pdf (accessed 20 April 2020).

7. Verkhovna Rada of Ukraine (1999). The Law of Ukraine «On Accounting and Financial Reporting in Ukraine» № 996-XIV (1999, July 16). Retrieved from: http://zakon3.rada.gov.ua/laws/show/996-14 (accessed 20 April 2020).

8. Ministerstvo finansiv Ukrainy (2013). Natsionalne polozhennia (standart) bukhhalterskoho obliku 1 «Zahalni vymohy do finansovoi zvitnosti» [National Accounting Standard 1 «General Requirements for Financial Statements»]. Retrieved from: http://zakon4.rada.gov.ua (accessed 20 April 2020).

9. Podoljanchuk, O. A. (2018). Oblikova informacija ta jiji jakisni kharakterystyky vidpovidno do oblikovykh standartiv [Accounting information and its quali- 
tative characteristics in accordance with accounting standards]. Economy. Finance. Management: current issues of science and practice, no. 8, pp. 79-90.

10. Panchenk, I. (2014). Vymoghy do informaciji, shho mistytjsja u finzvitnosti, skladenij za MSFZ [Requirements for information contained in IFRS financial statements]. Retrieved from: https:/uteka.ua/ua/publication/commerce-12msfo-28-trebovaniya-k-informacii-v-finotchetnosti-sostavlennoj-po-msfo (accessed 29 April 2020).

11. Fesenko, V. V., \& Zaghoreljsjska, T. Ju. (2015). Oblikovi vykryvlennja ta jikh vplyv na finansovu zvitnistj [Accounting misstatements and their impact on the financial statements]. Global and national economic problems, vol. 5, pp. 1040-1043.

12. Ministerstvo finansiv Ukrainy (2013). Metodychni rekomendaciji shhodo zapovnennja form finansovoji zvitnosti [Methodical recommendations for filling out financial reporting forms]. Retrieved from: http://minfin.kmu.gov.ua/control/ $\mathrm{uk} /$ publish/article $/$ main?art_id $=382876 \&$ search_param $=\% \mathrm{EE} \% \mathrm{E} 1 \% \mathrm{~B} 3 \% \mathrm{E} 3 \&$ searchPublishing=1 (accessed 22 April 2020).

13. Ministerstvo finansiv Ukrainy (2000). Natsionalne polozhennia (standart) bukhhalterskoho obliku 25 «Sproshhena finansova zvitnistj» [National Accounting Standard 25 «Simplified financial Reporting»]. Retrieved from: https://ips.ligazakon.net/document/view/REG4382?an=5 (accessed 25 April 2020). 